ANNALS, AAPSS, 486, July 1986

\title{
Campaign Finance Reform: The Unfinished Agenda
}

\author{
By FRED WERTHEIMER
}

\begin{abstract}
In 1974, following the Watergate scandal, Congress enacted major campaign finance reform legislation. The legislation created a revolutionary new public financing system for our presidential campaigns, but it left congressional campaigns to be financed totally by private money. The presidential public financing system has worked well. Despite some incremental problems, the system has accomplished its basic goal of allowing individuals to run for the presidency without becoming dependent on their financial backers. The system for financing congressional campaigns, on the other hand, is out of control and in need of fundamental reform. The inappropriate role of special interest political action committees (PACs) in influencing congressional elections and congressional decisions is the single biggest problem facing the political process. Congress needs to complete the unfinished campaign finance reform agenda of the 1970s by enacting public financing for congressional campaigns and establishing new restrictions on the total amount that PACs may give to a congressional candidate.
\end{abstract}

Fred Wertheimer is president of Common Cause, a national citizens'lobbying organization. He joined the organization as a lobbyist in 1971 and became president in 1981. He has been Common Cause's chief lobbyist on campaign finance reform and served as director of its Campaign Finance Monitoring Project. Before joining Common Cause, he served as minority counsel to the House Small Business Committee, as legislative counsel to Congressman Silvio Conte, and as an attorney with the Securities and Exchange Commission. Mr. Wertheimer is a graduate of the University of Michigan and Harvard Law School.

NOTE: The author wishes to acknowledge the impurtant contributions made in the preparation of this article by Common Cause staff members Marcy Frosh, Carole Geithner, Randy Huwa, Ann McBride, and Jane Mentzinger. 
$\mathrm{O}$ UR democracy is founded on the concept of representation. Citizens elect leaders who are given responsibility to weigh all the competing and conflicting interests that reflect our diversity and to decide what, in their judgment, will best advance the interests of the citizenry.

It is obviously a rough system. It often does not measure up to the ideal we might hope to attain. But we continue to place our trust in this system because we believe our best chance at governing ourselves lies in obtaining the best judgment of elected representatives.

Unfortunately, that is not happening today. We are not obtaining the best judgment of our elected representatives in Congress because they are not free to give it to us. As a result of our present congressional campaign financing system-and the increasing role of political action committee (PAC) campaign contributions - members of Congress are rapidly losing their ability to represent the constituencies that have elected them.

We have long struggled to prevent money from being used to influence government decisions. We have not always succeeded, but we have never lost sight of the goal. Buying influence violates our most fundamental democratic values. We have long recognized that the ability to make large campaign contributions does, in fact, make some more equal than others. In the mid1960s, for example, Senator Russell Long, Democrat of Louisiana, observed,

One sweet woman was on the opposite side [in an election] and thought they were going to lose and came charging in there with a couple of hundred thousand dollars to pump up their side. . . . Anybody who would suggest that she had no more influence than any other sweet old lady in a calico dress just does not know anything about politics: ${ }^{1}$

Beginning in the early 1970s, Common Cause and other election reform groups pressed for fundamental changes in the campaign finance statutes. The goals were to end secrecy in campaign financing, to limit the influence of large contributions, to enable candidates of modest means to seek office without becoming beholden to campaign donors, and to increase competition in the political process. The reform agenda called for:

-effective campaign contribution and expenditure reporting requirements;

- limits on the size of individual and group campaign contributions;

-a system of public financing of campaigns, including candidate access to federal funds and limits on spending; and

-effective enforcement by an independent agency.

This reform agenda took on a new importance in the wake of Watergate, our nation's greatest political scandal. Watergate revealed that our government was literally up for sale. The money came in the form of funds contributed for the presidential campaign. As the then chairman of American Airlines explained:

The law ... is based on a system by which candidates for public office must seek funds from persons affected by the actions of such candidates when elected to office. The sys-

1. U.S., Congress, Senate, Committee on Finance, Hearings on $S$. 3496, Amendment No. 732, S. 2006, S. 2965, and S. 3014, 89th Cong., 2d sess., 1966, p. 78 . 
tem provides no limits on the total amount that may be raised or spent and hence places a premium on pressure to raise greater and greater amounts. ${ }^{2}$

In its final report, the Senate Watergate Committee concluded that, as a result of the systematic solicitation of corporate donors, 12 major corporations gave approximately $\$ 749,000$ in illegal contributions to the Nixon campaign. $^{3}$ Corporate executives testified that they succumbed to such solicitations as a way of gaining access to administration decision makers and also out of fear of experiencing competitive disadvantages if they failed to contribute. Said one Gulf Oil executive, "I considered it considerable pressure when two Cabinet officers and an agent of one of the committees that was handling the election ... ask[ed] me for funds-that is just a little bit different than somebody collecting for the Boy Scouts." 4

The Milk Producers Association's pledge of \$2 million to President Nixon's reelection campaign was linked in the public's mind to the increase in milk price supports. More than $\$ 1.8$ million in contributions to the Nixon campaign came from people who received ambassadorial appointments during his administration. $^{5}$

2. D. Michal Freedman, The Watergate Reforms: Ten Years After (Washington, DC: Common Cause, 1983), p. 16.

3. U.S., Congress, Senate, Select Committee on Presidential Campaign Activities, Final Report, 93rd Cong., 2d sess., 1974, p. 446.

4. Ibid., p. 471.

5. Ibid., pp. 127, 492-93, 579. See Fred Wertheimer and Randy Huwa, "Campaign Finance Reforms: Past Accomplishments, Future Challenges," New York University Review of Law and Social Change, 10:44 (1980-81). Unless otherwise noted, figures used in this article are based on analyses prepared by Common Cause of campaign finance disclosure statements filed with the Federal Election Commission.
Reflecting on the meaning of Watergate, John Gardner, founder and former chairman of Common Cause, wrote at the time:

In almost every aspect of Watergate, there was one common element: the flow of secret campaign cash. There are honest donors to political campaigns and honest recipients; but the existence of these does not outweigh the fact that the present system legitimizes the buying and selling of politicians. The old-style, flat-footed cash bribe has been replaced by the campaign gift, its all-purpose, prepackaged modern equivalent. ${ }^{6}$

The result of these revelations, not surprisingly, was an alarming drop in citizens' confidence in their government. Pollster Louis Harris in 1973 told a Senate committee that "public confidence in government generally must be reported as being lower than a constituent democracy can afford."7

The nation's greatest political scandal led to one of the nation's most historic and revolutionary reforms, the public financing of our presidential elections. Congress enacted public financing to prevent private campaign contributions from being used as a vehicle for obtaining influence with the president of the United States. Under this system, limits were placed on the size of contributions, overall expenditures were capped, and an alternative source of campaign money was created: public funds generated by the dollar checkoff on the federal income tax. ${ }^{8}$

6. Freedman, Watergate Reforms, p. 17.

7. U.S., Congress, Senate, Committee on Government Operations, Hearings on a Survey of Public Attitudes, 93rd Cong., 1st sess., 1973, pp. 6-8.

8. FECA Amendments of 1974, Pub. L. No. 93-443, §§ 101-302, 88 Stat. 1263 (1974) (codified as amended in scattered sections of $2,5,18,26,47$ U.S.C.). 
Unfortunately, the same progress was not made at the congressional level. Although Congress established limits on contributions by both individuals and PACs and placed limits on overall expenditures, ${ }^{9}$ members of Congress were unwilling to take the last crucial step-to establish an alternative public source of campaign funds for their own campaigns. While congressional public financing was passed by the Senate, the House narrowly rejected it, by a vote of 187 to 228 , and the provision was dropped in conference. At the same time, in a major step backward and over the objections of reform groups, Congress opened the door for an increased role in special interest giving by repealing a prohibition on the formation of PACs by government contractors. ${ }^{10}$ As a result of these actions, campaign contributions remain a powerful vehicle for obtaining access and influence in the United States Congress.

The presidential and congressional campaign-financing systems thus require sharply different types of reform today. Comprehensive legislation must be enacted to remedy the defects in the system for financing congressional campaigns. Limits on overall PAC receipts must be established. A public financing system must be created to provide overall spending limits and adequate alternative funding so that candidates are no longer dependent on special interest group contributions. In contrast, the system of financing presidential campaigns has already been successfully transformed. While significant adjustments are needed in order to deal with

9. The limits on overall expenditures were struck down by the Supreme Court in the landmark case Buckley v. Valeo, 424 U.S. 1 (1976).

10. Act of 14 June 1940 , chap. $640, \S 5$ (a), 54 Stat. 772 (repealed 1976). new problems that have arisen, such as soft money and independent expenditures, these changes are required to preserve the integrity of an existing system that has accomplished its basic goals.

\section{PRESIDENTIAL PUBLIC FINANCING}

Simply stated, the presidential public financing system is an idea that works; it is the crowning achievement of the amendments adopted in 1974 to the Federal Election Campaign Act. Under the system, candidates who agree to abide by limits on overall campaign spending and the expenditure of personal wealth are able to receive federal tax dollars, funds designated to a separate account by individual taxpayers. Public funds are available to match small private contributions raised by candidates during the nominating process; for the general election, majorparty candidates are entitled to full campaign funding with public dollars.

In the three elections for which this new system has been in place-1976, 1980, and 1984-presidential public financing has been successful. Thirtyfour of the 35 major party candidates since the law was passed have chosen to participate in this voluntary system. Presidential public financing has checked the increase in presidential campaign expenditures. Presidential contenders no longer must "tin-cup it around the country" in search of campaign funds. " In contrast to the presidential contest of 1972, candidates are no longer dependent on a relatively few fat-cat contributors; rather, the funding base for campaigns is broad. PAC contributions play a

11. "Fat Cat as Endangered Species," Washington Post, 26 June 1980. 
minor role in presidential campaigns. PACs gave less than $\$ 1.5$ million to 1984 presidential candidates, or less than 2 percent of the total funds raised. As the New York Times has observed, "Public financing confers on Presidential candidates the freedom not to grovel." 12

Public financing also confers an added freedom to govern without the strings attached by large donors or public suspicion that such strings exist. The Carter and Reagan presidencies have been relatively free of the hint that government favors have been traded for large campaign contributions. Stories linking the influence of campaign contributions with official actions in the legislative branch are common; ${ }^{13}$ for the executive branch, very rare. The Commission on National Elections, headed by Melvin Laird and Robert Strauss, concluded,

Public financing of presidential elections has clearly proved its worth in opening up the process, reducing undue influence of individuals and groups, and virtually ending corruption in presidential election finance.

12. "Sneak Attack on Campaign Finance," New York Times, 3 June 1985.

13. See, for example, Common Cause, How Money Talks in Congress: A Common Cause Study of the Impact of Money on Congressional Decision-Making (Washington, DC: Common Cause, 1979); Wertheimer and Huwa, "Campaign Finance Reforms: Past Accomplishments, Future Challenges," pp. 49, 51, 52, 53; Walter Isaacson, "Running with the PACs" Time, 25 Oct. 1982, pp. 20-26; Brooks Jackson and Jeffrey Birnbaum, "Dairy Lobby Obtains U.S. Subsidies with Help from Urban Legislators," Wall Street Journal, 18 Nov. 1983; Judith Bender, "The PAC Game on Capitol Hill," Newsday, 12 Mar. 1984; Brooks Jackson, "PAC Helps Push Pet Electric Bill," Wall Street Journal, 29 Mar. 1984; and Jeffrey Sheler and Robert Black, "Is Congress for Sale?" U.S. News and World Report, 28 May 1984, pp. $47-50$.
This major reform of the 1970's should be continued. $^{14}$

\section{CONGRESSIONAL CAMPAIGN FINANCING}

While the presidential campaign finance system stands as a model for reform, the congressional campaign system is out of control and in need of fundamental repair.

The last decade of congressional campaign financing has been marked by an exponential increase in the number of PACs formed by corporations, labor unions, trade associations, and other groups. In 1974 there were 608 PACs. Today there are more than 4000 .

This explosion in PACs can be traced to congressional action - and inactionin 1974. Ironically, at the very time when members of Congress were acting to clean up presidential elections, they opened the door for PACs to enter the congressional arena in an unprecedented way. The key to the PAC explosion was a provision attached to the 1974 law by labor and business groups, over the opposition of Common Cause and other reform advocates, that authorized government contractors to establish PACs. ${ }^{15}$ In addition, by creating public financing for presidential campaigns, but not for congressional races, the 1974 amendments focused the attention and interest of PACs and other private campaign donors on Congress.

The resulting growth in PACs was no accident, and it certainly was not a reform. The growth of PACs, moreover, is certainly no unintended consequence of the 1974 law-the provision was

14. Report of the Commission on National Elections, Executive Summary (Washington, DC: Georgetown University, Center for Strategic and International Studies, 1985), p. 7.

15. 2 U.S.C. $\$ 44 \mathrm{lc}$ (b) (1976). 
included to protect and enhance the role of PACs in financing campaigns, and it has.

This tremendous increase in the number of PACs has not resulted in balanced representation in Washington. As Senator Gary Hart, Democrat of Colorado, has told the Senate:

It seems the only group without a well-heeled PAC is the average citizen-the voter who has no special interest beyond low taxes, an efficient government, an honorable Congress, and a humane society. Those are the demands we should be heeding-but those are the demands the PACs have drowned out. ${ }^{16}$

In fact, the increasing number of PACs has largely served to increase the ability of single interests to bring pressure to bear on a congressional candidate or a member of Congress. There are more than 100 insurance company PACs, more than 100 PACs sponsored by electric utilities, and more than 300 sponsored by labor unions. Representative David Obey, Democrat of Wisconsin, has observed that frequently in Washington

an issue affects an entire industry and all of the companies and labor unions in that industry.... When that occurs, [and] a large number of groups which have made substantial contributions to members are all lobbying on the same side of an issue, the pressure generated from those aggregate contributions is enormous and warps the process. It is as if they had made a single, extremely large contribution. ${ }^{17}$

The increase in the number of PACs, not surprisingly, has also produced a

16. U.S., Congress, Senate, Congressional Record, 99th Cong., 1st sess., 131(165): 16683.

17. Statement of Congressman David R. Obey, Democratic Study Group, 26 July 1979, quoted in Fred Wertheimer, "The PAC Phenomenon in American Politics," Arizona Law Review, 22:622-23, n. 114 (1980). tremendous increase in PAC contributions to congressional candidates. In 1974, PACs gave $\$ 12.5$ million to congressional candidates. By the 1984 elections, their contributions had exceeded $\$ 100$ million, an eightfold increase in ten years.

PAC money also represents a far more important part of the average candidate's campaign funds than it did ten or so years ago. In 1974, 15.7 percent of congressional candidates' campaign money came from PACs; by the 1984 election, that proportion had increased to 30 percent.

Yet these numbers only begin to tell the story. The increased dependence on PAC contributions has been greatest for winners, those individuals who serve in Congress and who cast votes that shape our daily lives. In the Ninety-ninth Congress (1985-86), over 150 House members received 50 percent or more of their campaign funds from PACs, including 20 of the 27 committee chairs and party leaders. House winners in the 1984 election received an average of 41 percent of their campaign dollars from PACs. Of all winning House candidates in the 1974 election, only 28 percent received one-third or more of their campaign funds from PACs. By 1984, that figure had grown to 78 percent.

For senators, PAC contributions are also becoming a more important source of campaign dollars. Senators elected in 1976 received a total of $\$ 3.1$ million from PACs; Senate winners in the 1984 election raised $\$ 20$ million from PACs. In the 1984 elections, 23 winning Senate candidates raised more than $\$ 500,000$ each from PACs.

Some have suggested that the growth in PACs is an important new form of citizen involvement in the political process. Yet PAC participation is often 
likely to be more of an involvement in the corporate process or the union process or the trade association process than it is in the political process. University of Minnesota professor Frank J. Sorauf has noted:

To understand political participation through PACs, we need also to note the nature of the participation. Some of it is not even political activity; buying a ticket in a raffle, the proceeds of which go to a PAC, a party, or a candidate, does not qualify as a political act by most standards. Even the contributory act of writing a check or giving cash to a PAC is a somewhat limited form of participation that requires little time or immediate involvement; in a sense it buys political mercenaries who free the contributor from the need to be personally active in the campaign. It is one of the least active forms of political activity, well suited to the very busy or to those who find politics strange, boring, or distasteful. ${ }^{18}$

In fact, the growth of PACs and the increased importance of PAC money have had a negative effect on two different parts of the political processcongressional elections and congressional decision making. First, PAC money tends to make congressional campaigns less competitive because of the overwhelming advantage enjoyed by incumbents in PAC fund-raising. The ratio of $\mathrm{PAC}$ contributions to incumbents over challengers in 1984 House races was 4.6 to 1.0 ; in the Senate, incumbents in 1984 enjoyed a 3.0 to 1.0 advantage in PAC receipts. On the average, 1984 House incumbents raised $\$ 100,000$ more from PACs than did challengers. This $\$ 100,000$ advantage was true even in the most highly competitive House

18. Frank Sorauf, "PACs in the American Political System" (Background paper, Twentieth Century Fund Task Force on Political Action Committees, 1984), pp. 82-83. races, those in which the incumbent received 55 percent or less of the vote. In these races, incumbents received an average of over $\$ 230,000$ from PACs; their challengers received less than $\$ 110,000$. The advantage enjoyed by incumbents is true for all kinds of PAC giving-for contributions by labor groups, corporate $\mathrm{PACs}$, and trade and membership PACs.

Second, there is a growing awareness that PAC money makes a difference in the legislative process, a difference that is inimical to our democracy. PAC dollars are given by special interest groups to gain special access and special influence in Washington. Most often, PAC contributions are made with a legislative purpose in mind. The late Justin Dart, former chairman of Dart Industries, once noted that dialogue with politicians "is a fine thing, but with a little money they hear you better."19 Senator Charles Mathias, Republican of Maryland, has stated:

An official may not change his or her vote solely to accommodate the views of such contributors, but often officials, including myself, will agree to meet with an individual who made a large contribution so the official can hear the contributor's concerns and make the contributor aware these concerns have been considered. ... Since an elected official has only so much time available, the inevitable result of such special treatment for the large contributor is that other citizens are denied the opportunity they otherwise would have to confer with the elected official. ${ }^{20}$

Common Cause and others have produced a number of studies that show a relationship between PAC contributions

19. "Companies Organize Employees and Holders into a Political Force," Wall Street Journal, 15 Aug. 1978.

20. Brief for Appellees, p. 53, Buckley v. Valeo, 424 U.S. 1 (1976). 
and legislative behavior. The examples run the gamut of legislative decisions, including hospital cost containment, the Clean Air Act, domestic content legislation, dairy price programs, gun control, maritime policies, and regulation by the Federal Trade Commission of professional groups or of used-car sales. ${ }^{21}$

PAC gifts do not guarantee votes or support. PACs do not always win. But PAC contributions do provide donors with critical access and influence; they do affect legislative decisions and are increasingly dominating and paralyzing the legislative process.

In the last few years, something very important and fundamental has happened in this country-and that is the development of a growing awareness and recognition of the fact that the PAC system is a rotten system that must be changed. We know that concern is growing when Irving Shapiro, former chairman and chief executive officer of duPont and the former chairman of the Business Roundtable, describes the current system of financing congressional campaigns as "an invidious thing, it's corrupting, it does pollute the system."22

We know that concern is reaching new audiences when Business Week editorializes that

fears are growing that the proliferation of PACs ... is balkanizing the nation's political

21. See, for example, Common Cause, "How Money Talks in Congress"; Wertheimer and Huwa, "Campaign Finance Reforms: Past Accomplishments, Future Challenges,"pp. 49, 51, 52, 53; Isaacson, "Running with the PACs," pp. 20-26; Jackson and Birnbaum, "Dairy Lobby Obtains U.S. Subsidies"; Bender, "PAC Game on Capitol Hill"; Jackson, "PAC Helps Push Pet Electric Bill"; and Sheler and Black, "Is Congress for Sale?"

22. Nina Easton, "Swimming against the Tide," Common Cause Magazine, 9(5):13 (Sept.Oct. 1983). process as swarms of candidates and wellheeled special interest groups jostle to trade political favors for money. ... It would be hard to find a PAC that gives solely to support good government. Most see their contribution as an investment in promoting laws favoring their interests. ${ }^{23}$

\section{And Chemical Week warns:}

[A] new force has intruded into our system of representative democracy that, if unchecked, could topple it or seriously hurt it. We refer to the phenomenon of Political Action Committees. . . The plain truth of the matter, no matter what gloss is put on it, is that PAC money aims at influencing congressional action. The other side of the coin is that new candidates and incumbents alike become beholden to their PAC benefactors. That's the whole point, isn't it? ? $^{24}$

Criticism of the PAC system is also increasingly heard in the halls of Congress. More and more members from both parties are speaking out about the PAC problem. Consider the following:

[The present campaign-financing system] virtually forces members of Congress to go around hat in hand, begging for money from Washington-based special interest political action committees, whose sole purpose for existing is to seek a quid pro quo. ... the scandal is taking place every day and will continue to do so while the present system is in place. ${ }^{25}$

PAC money is destroying the election process. It is breaking down public confidence in

23. "How to Curb PAC Power but Not Free Speech," Business Week, 22 Nov. 1982.

24. Patrick P. McCurdy, "Let's Pack in the PACs-All of Them," Chemical Week, 15 Aug. 1984, p. 3.

25. Statement of Senator Thomas Eagleton, in U.S., Congress, Senate, Committee on Rules and Administration, Hearings on Campaign Finance Reform Proposals of 1983, 98th Cong., 1st sess., 1983, p. 52. 
free elections and it is ruining the character and quality of campaigns. ${ }^{26}$

In addition, the growth in the influence of PAC's further fragments our Nation and its elected legislative bodies. It makes it increasingly difficult to reach a national consensus and hold[s] our decisionmaking process hostage to the special interests which PAC's represent.... We cannot expect Members of Congress to act in the national interest when their election campaigns are being financed more and more by special interests. ${ }^{27}$

In addition to the growing role of PAC contributions, the congressional campaign-financing system is also marked by unlimited and skyrocketing spending. In 1974, House and Senate candidates spent $\$ 77$ million on congressional races. Ten years later, House and Senate candidates spent a record $\$ 374$ million, almost five times as much.

The cost of winning a seat in Congress is also rising dramatically. In the 1975-76 election cycle, House winners spent $\$ 38$ million, an average of over $\$ 87,000$ each. In the $1983-84$ election cycle, House winners spent $\$ 117$ million, an average of $\$ 269,956$ each. On the Senate side, winners spent $\$ 20$ million in the 1975-76 cycle, an average of $\$ 606,060$; in 1984 elections, Senate winners spent $\$ 94.8$ million, an average of $\$ 2.9$ million each.

About rising campaign expenditures Senator Goldwater has said,

Unlimited campaign spending eats at the heart of the democratic process. It feeds the growth of special interest groups created solely to channel money into political campaigns. ... And it causes elected officials to

26. Remarks of Senator Barry Goldwater, in U.S., Congress, Senate, Congressional Record, 99th Cong., Ist sess., 131(165):16679.

27. Remarks of Senator David Boren, in ibid., no. 164 , p. 16605 . devote more time to raising money than to their public duties. ${ }^{28}$

And Senator Eagleton has said on the Senate floor:

Throughout the last decade, the money factor has exploded exponentially. Most of us have our "tin cups" for alms-begging; our call lists to fat cats; our endless procession of fundraising receptions; our direct mail pleas; and so forth.

The money race never ends. Senators start the process in the early years of their 6-year terms by "building a war chest" for their reelection. House Members start on the Wednesday after the Tuesday elections to amass the funds for the next go-around. ${ }^{29}$

\section{THE CAMPAIGN FINANCE REFORM AGENDA}

A number of changes in federal election law are needed if the campaign finance reform effort begun over a decade ago is to be finished. In some cases, unfinished business needs to be completed. The foremost item of old business, of course, is a fundamental restructuring of the congressional campaign-financing system. In addition, new problems that have emerged in the years since Watergate need to be addressed. Adjustments to the presidential public financing system-a system that is fundamentally sound and that has demonstrated its effectiveness-need to be made. A campaign finance reform agenda today should include congressional campaign finance reform, independent expenditures, and soft money, as well as other issues.

28. U.S., Congress, Senate, Committee on Rules and Administration, Hearings on Campaign Finance Reform Proposals of 1983, p. 403.

29. U.S., Congress, Senate, Congressional Record. 99th Cong., Ist sess., 131(165):16683. 


\section{Congressional campaign finance reform}

The major unfinished business on the reform agenda is a thorough overhaul of the congressional campaign finance system. Comprehensive legislation is needed that includes the following essential components: limitations on overall PAC receipts, provision of an alternative campaign fund source, and limits on overall campaign spending and on the expenditure of a candidate's personal funds.

Limitations on overall $P A C$ receipts. While current law restricts the amount that an individual PAC may give to a candidate, there is no restriction on the total amount that a candidate may accept from all PACs. Thus in the last two elections we have seen four Senate candidates who have each accepted more than \$1 million in PAC funds. An overall limit on aggregate $P A C$ receipts would help shift the focus of congressional fund-raising away from large PAC contributions and back to small contributions from individual donors.

An amendment establishing an overall limit on PAC receipts was adopted by the House in 1979-the Obey-Railsback bill-but was not considered by the Senate. The introduction in 1985 of a PAC-limit amendment by Senators Boren and Goldwater revived congressional consideration of the concept of an aggregate PAC limit. ${ }^{30}$

Alternative campaign funds. Essential to the presidential public financing system are the federal funds made available to presidential candidates. Congressional campaign finance reform

30. S. 1806 , printed in ibid., no. 146 , p. 14360 ; debate on S. 1806 is found in ibid., no 164 , p. 16603 ; see also ibid., no. 165 , p. 16678. legislation similarly needs to provide alternative sources of campaign funds to candidates. This could be done in the form of public funds to match small contributions from individuals, as is done in the presidential nominating process, or grants to candidates, as is done in the presidential general election, or a 100 percent tax credit for small contributions to candidates, ${ }^{31}$ or some combination of these systems. The creation of a broad-based alternative financing system will once again make elective office a realistic ambition for individuals without personal fortunes and for those who are unwilling or unable to raise large sums from PACs.

Overall campaign spending and candidates'personal funds. Limits on overall spending and the use of personal funds are a key feature of the presidential public financing system and are needed for congressional campaigns as well. The Supreme Court in its 1976 Buckley decision upheld the constitutionality of such limits as part of a system providing public financing for presidential candidates, but the Court struck down the spending limits enacted for congressional races because they were not tied to any public campaign finance system. It is clear from the Buckley decision that limits for congressional races along with limits on the use of personal funds can be constitutionally enacted as part of a public finance campaign system.

In crafting reform legislation, it is important to ensure that spending limits are set at levels high enough to allow

31. See, for example, H.R. 2490, printed in U.S., Congress, House, Congressional Record, 98th Cong., Ist sess., 129(45):1992; H.R. 4428, in ibid., no. 159, p. 10056; and U.S., Congress, Senate, Congressional Record, 99th Cong., 1st sess., 131(143): 14065. 
challengers to run competitive campaigns. Since any campaign-financing system that includes spending limits must be voluntary under the Buckley decision, candidates who felt unable to wage effective congressional campaigns within the spending limits would be free to run their races without public financing. Those who claim that public financing with spending limits favors the reelection of incumbents should not lose sight of the fact that in the first two presidential elections conducted under the presidential public financing system-1976 and 1980-incumbents were defeated, for the first time since 1932 . Nor should these critics forget that it is incumbent members of Congress who thus far have failed to rush to enact public financing for congressional races. For the past decade a majority of incumbent members do not appear to have reached the conclusion that public financing and spending limits are an incumbent's advantage.

Enactment of a new campaign-financing system for Congress would free our elected representatives from their dangerous dependence on special interest contributions. A new system is also essential if we are to restore public confidence in the integrity of Congress and its members.

Two additional major changes are needed to protect the integrity of the presidential public financing system and any new system established for congressional campaigns. The changes deal with the issues of independent expenditures and soft money.

\section{Independent expenditures}

Under the Court's decision in Buckley, contributions made directly to a candidate may constitutionally be lim- ited, but no limits may be imposed on expenditures undertaken independently by a PAC or an individual on behalf of or in opposition to a candidate. Through these so-called independent expenditures, PACs and individuals can evade the intent of limits on direct contributions. They can and do spend substantial sums - far in excess of statutory contribution limits-supporting or attacking candidates.

Independent spenders are unaccountable. They do not have to assume responsibility at election time, nor do they face the political impact of any misrepresentation they may make. A leader in the independent spending movement, Terry Dolan of the National Conservative Political Action Committee, has said, "A group like ours could lie through its teeth and the candidate it helps stays clean." ${ }^{32}$

The persistent use of independent spending in politics alters the political process for the worse. ${ }^{33}$ Independent spending can seriously distort the competition between candidates. Candidates are faced with spending not only by their opponents but also by independent groups. Senator Ernest Hollings, Democrat of South Carolina, has noted, "We all have seen how PACs can seriously damage the balance in a campaign through the expenditure of enormous amounts of money. In effect, a candidate budgets to fight one well-financed opponent but then ends up fighting many., ${ }^{34}$

32. Myra MacPherson, "The New Right Brigade," Washington Post, 10 Aug. 1980.

33. See, for example, David Broder, "Equal Time for Targets," Washington Post, 26 Aug. 1981; "Nick-Pack Strikes Home," New York Times, 18 Nov. 1981.

34. U.S., Congress, Senate, Congressional Record, 99th Cong., Ist sess., 131(80):8268. 
Within the confines of the Supreme Court's decisions in Buckley and later cases, there are steps that can and should be taken to curb the impact of independent expenditures. First, the Buckley decision specified that independent expenditure activities are exempt from limitation only if they are not coordinated with candidates or the agents of candidates. Additional legislation and regulations should be developed to clarify the standards to be used in assessing the true independence of an expenditure campaign. ${ }^{35}$

Second, and more important, the federal communication statutes should be amended to provide to federal candidates free and equal time to respond to broadcast advertisements purchased by means of independent expenditures. Under a response-time proposal, radio and television stations would be required to provide free and equal time to candidates for federal office in cases where a broadcaster sells time to any person - aside from federal candidatesto broadcast material that either endorses or opposes a candidate. If the broadcast advertisement opposes a candidate, that candidate would be entitled at no cost to an equal amount of broadcast time. If the broadcast advertisement endorses a candidate, other legally qualified candidates for the same office would be entitled at no cost to an equal amount of broadcast time. The responsetime concept builds upon existing responsibilities placed on broadcasterssuch as the personal-attack rule-and is a constitutional extension of existing communication standards that have been upheld by the courts.

35. Wertheimer and Huwa, "Campaign Finance Reforms: Past Accomplishments, Future Challenges," p. 64.
Response time would help to protect the integrity of the present system of contribution limits by assuring that a candidate could respond without major expense to an independent expenditure campaign. Response time would enable candidates to refute misrepresentations made by independent spenders. A response-time proposal would not end independent expenditures, but it would restore some measure of accountability to independent spending activities. ${ }^{36}$

The response-time proposal has been included as a major provision of S. 1310, the Clean Campaign Act of 1985, introduced in the Ninety-ninth Congress by Senators John Danforth, Republican of Missouri, Ernest Hollings, Democrat of South Carolina, and Barry Goldwater, Republican of Arizona. ${ }^{37}$ This proposal

36. Fred Wertheimer, "Fixing Election Law," New York Times, 3 Sept. 1981. See also Ronald Brownstein, "Soft Money," National Journal, 7 Dec. 1985, p. 2828; Center for Responsive Politics, Money and Politics: Soft Money-A Loophole for the ' 80 s (Washington, DC: Center for Responsive Politics, 1985); Common Cause, "Comments of Common Cause with Respect to Its Petition for Rulemaking Regarding 'Soft Money,' " (Manuscript, Common Cause, 1985); Elizabeth Drew, Politics and Money: The New Road to Corruption (New York: Macmillan, 1983); Thomas Edsall, "Loophole Lets Parties Raise Millions from Firms, Unions," Washington Post, 17 Apr. 1984; idem, “'Soft Money' Will Finance Voter Sign Up,"ibid., 12 Aug. 1984; Maxwell Glen, "Republicans and Democrats Battling to Raise Big Bucks for Voter Drives," National Journal, Sept. 1984, pp. 1618-22; "Soft Money," Washington Post, 31 Aug. 1984; "The Soft-Money Loophole," ibid., 1 Nov. 1985; Ed Zuckerman, "Lobbying and Campaign Ethics: The Ethical Implications of 'Soft Money' " (Remarks delivered at George Washington University, Washington, DC, 28 Oct. 1985); idem, "Democrat 'Soft Money' Nets Catch $\$ 30$ Million," PACs \& Lobbies, 21 Nov. 1984; idem, "'Soft Money': A New Life for 'Fat Cats,'” ibid., 16 Jan. 1985; and idem, "More DNC 'Soft Money' Accounts Found," ibid., 6 Feb. 1985.

37. U.S., Congress, Senate, Congressional 
is also a significant component of the Boren-Goldwater PAC-limitation amendment. $^{38}$

\section{Soft money}

In federal elections the amounts that individuals and PACs may contribute are limited; direct contributions from corporations and unions are completely barred; and all contributions in excess of $\$ 200$ are subject to public-disclosure requirements. In many states, however, parallel regulations do not exist. In the 1980 s, so-called soft money has increasingly been funneled to state party organizations. Soft money funds are contributions from sources-corporations or unions - that are not permitted to make any direct contributions in federal elections, and contributions from individuals or groups in amounts above the federal limits.

While soft money is purportedly for use in party-building activities at the state and local levels, there is increasing evidence that these funds are in fact being spent in connection with federal candidates, particularly presidential candidates, in violation of federal law. This is one of the most serious problems in the campaign finance area today. This practice seriously undermines the integrity of the contribution limits and prohibitions contained in the federal law, including the limits on contributions by political parties, the expenditure limits in the presidential public financing sys-

Record, 99th Cong., lst sess., 131(80):8267; see also Congress, Senate, Committee on Commerce, Science and Transportation, Hearings on S. 1310 , the Clean Campaign Act of 1985, 99th Cong., 1st sess., 10 Sept. 1985; ibid., 8 Oct. 1985.

38. U.S., Congress, Senate, Congressional Record, 99th Cong., lst sess., 131(146):14361. tem, and disclosure requirements of the federal election law. ${ }^{39}$

In 1984, Common Cause proposed to the Federal Election Commission (FEC) that new regulations be adopted to control the use of the soft-money subterfuge. Under these regulations, national-level political party committees, including party congressional campaign committees, and federal officials would be prohibited from establishing soft-money accounts or from otherwise channeling to state parties for use in federal campaigns contributions that would be illegal under federal law. ${ }^{40}$

A number of additional campaign finance issues have arisen in the 1980s

39. See, for example, Brownstein, "Soft Money," p. 2828; Center for Responsive Politics, Money and Politics: Soft Money; Common Cause, "Comments of Common Cause with Respect to Its Petition"; Drew, Politics and Money; Edsall, "Loophole Lets Parties Raise"; idem, " 'Soft Money' Will Finance Voter Sign Up"; Glen, "Republicans and Democrats Battling," pp. 1618-22; "Soft Money," Washington Post; "Soft Money Loophole"; Zuckerman, "Lobbying and Campaign Ethics"; idem, "Democrat 'Soft Money' "; idem, " 'Soft Money': A New Life"; and idem, "More DNC 'Soft Money' Accounts Found."

40. In a 5 Nov. 1984 letter to Lee Ann Elliott, chair of the FEC, Common Cause urged the commission to take the following steps regarding soft money practices: (1) to initiate on a priority basis its own broad-ranging factual investigation into soft-money practices, with a view toward prosecuting actual past violations; (2) to initiate a rule-making proceeding to establish the broader administrative tools, such as additional disclosure requirements, needed to facilitate the commission's effective enforcement of the current laws; and (3) to undertake a review of the current laws to determine what additional statutory remedies may be required to assure that soft-money abuses are most effectively curtailed. On 4 Feb. 1985 Common Cause submitted to the FEC "Comments of Common Cause with Respect to Its Petition for Rulemaking Regarding 'Soft Money' " and thereby set out its formal proposal for rule making on soft money. 
that require legislative action. Congress should address delegate committee spending, candidate and officeholder PACs, presidential candidate foundations, bundling, the grandfather clause, and the FEC.

\section{Delegate}

\section{committee spending}

While presidential candidates who receive federal matching funds do so in return for a commitment to limit their overall and state-by-state spending, individuals who are seeking selection as delegates to a party's nominating convention are presently not subject to these limitations. Expenditures by the committees of these delegates create the capacity to bypass these spending limits, particularly if the expenditures are made at the direction of, with the encouragement of, or in conjunction with a candidate's campaign. ${ }^{41}$ Federal election law needs to be amended to apply the limitations on contributions and expenditures to convention delegates. ${ }^{42}$

\section{Candidate and}

\section{officeholder PACs}

A growing number of presidential candidates and members of Congress are establishing their own PACs. These

41. Similarly, delegate committees enable individuals and PACs to override the contribution limits to a presidential candidate by making multiple contributions to numerous delegate committees, all of which are intended to benefit directly a single presidential candidate's campaign. Such contributions serve to undermine the effectiveness of the existing contribution limits.

42. Thomas Edsall, "Candidates Find It Easy to Give Spending Curbs the Runaround," Washington Post, 3 June 1984; Brooks Jackson, "Loopholes Allow Flood of Campaign Giving by Businesses, Fat Cats," Wall Street Journal, 5 July 1984.
PACs, like others, may make campaign contributions. In many cases, particularly in the case of presidential hopefuls, these PACs are also used to finance a candidate's political travel and related expenses, expenditures that at this point do not count against the spending ceilings of the presidential public financing system. These PACs also allow larger individual and PAC contributions to be made to the candidate or officeholder involved than could be made to his or her candidate campaign committee. They also place officeholders and office seekers in the position of using PAC money to curry favor. Congress should ban the creation of PACs by members of Congress and by prospective candidates for president or vice-president. ${ }^{43}$

\section{Presidential \\ candidate foundations}

An increasing number of public figures, particularly prospective presidential candidates, have set up tax-exempt foundations. Unlike campaign committees, these foundations may accept unlimited amounts of money, including contributions from corporations and unions, and they are not required to report the source of their funds. Donations to these foundations, furthermore, are fully tax deductible.

These foundations, established to do research on issues and to undertake other educational activities, in theory are not linked to any individual. In practice, however, they can pay and have paid for travel by presidential hopefuls and have provided information that forms the basis of campaign position papers-activities that appear

43. See Maxwell Glen, "Starting a PAC May Be Candidates' First Step Down Long Road to 1988," National Journal, 16 Feb. 1985, pp. 374-77. 
to help promote the public officials who created them. ${ }^{44}$ At a minimum, taxexempt foundations that are controlled by or maintained for a political candidate should be required to disclose the source and amount of contributions received. ${ }^{45}$

\section{Bundling}

Another development on the campaign-financing landscape that Congress must address is bundling, a practice by which a PAC puts together, or bundles, numerous individual checks made out to a particular candidate's campaign and provides them to the candidate. This practice presently is being used by PACs effectively to evade the contribution limits of the federal election laws. By aggregating these individual contributions a single PAC can provide to a candidate amounts far in excess of the current $\$ 5000$-per-election limitation. A Wall Street Journal story, for example, noted that one insurance company PAC was able to funnel contributions of more than $\$ 168,000$ to one senator's reelection campaign through bundling. ${ }^{46}$

44. As David Spear, a spokesman for former Senate majority leader Howard Baker, has noted, "If it's not a violation of the law, it's certainly a violation of the spirit of the law . . candidates ought not to be able to raise campaign funds under the guise of a tax-free foundation." Bryan Abas, "Hart Has a Better Idea," Westword, 13-19 Nov. 1985, p. 8.

45. See Report of the Commission on National Elections, Executive Summary, p. 8; Paul West, “ 'Foundations' Are Promoting Politicians," Baltimore Sun, 29 Sept. 1985; and Thomas Edsall, “ '88 Candidates' New Tricks Stretch Federal Election Law,"Washington Post, 20 Oct. 1985.

46. Brooks Jackson, "Insurance Industry Boosts Political Contributions as Congress Takes up Cherished Tax Preferences," Wall Street Journal, 10 Oct. 1985. See also idem, "GOP Group Uses Cash Creatively," ibid., 13 Sept. 1984; and
Under current FEC regulations, the bundled contributions are not treated as a contribution by the intermediary PAC unless it actually controls the choice of the recipient. The result is a loophole that is increasingly being exploited by PACs to expand their capacity to exert influence and to undermine the contribution limits.

The bundling loophole should be closed by amending federal election law to provide that bundled contributions would count against the contribution limits of both the individual contributor and the intermediary person or PAC. That is, if a PAC collects or otherwise aggregates contributions that are earmarked or directed to a particular candidate's campaign and assists in transmitting these contributions to that campaign, the contributions will be considered contributions to the candidate by the conduit PAC as well as by the original individual contributor.

\section{Grandfather clause}

In 1979 Congress amended federal law to prohibit candidates from converting surplus campaign funds for personal use. Under a grandfather clause included in that amendment, however, any member of Congress who was in office on 8 January 1980 is permitted to keep his or her surplus campaign contributions for personal use after leaving Congress. Members who qualify under this provision may thus take campaign money upon retirement. These surplus campaign funds, in some cases, now range to amounts as high as $\$ 600,000$. While House and Senate rules prohibit conversion of these funds for personal

Michael Wines, "Bundling: A New U.S. Campaign Custom," Los Angeles Times, 3 Oct. 1981. 
use while members remain in office, several members who have retired have in fact converted surplus funds for personal use. Other members, still in Congress, seem to regard building up campaign surpluses as a new form of political individual retirement account. ${ }^{47}$

Congress already has recognized the problems inherent in allowing retiring members to convert contributions into personal funds by banning this activity for many members. It should complete the task started in 1979 and remove the grandfather clause, which allows some members to escape the ban.

\section{FEC}

While it is important to examine the rules for congressional and presidential campaign financing, a careful assessment must also be made of the FEC, the body responsible for enforcing federal election laws.

The commission has failed the public in several important respects. Most significantly, it is ponderously slow in its enforcement proceedings and is often prone to concentrate on technicalities rather than major issues of rule making. While the FEC's efforts at promoting disclosure of the receipts and expenditures of PACs and candidates have been a major success, lax enforcement by the

47. At the end of the 1984 election cycle, for instance, members of the House who could convert surplus funds upon retirement had average cash-on-hand figures of $\$ 106,935$; their colleagues who were not grandfathered averaged $\$ 50,421$. See Lee Norrgard, "You Can Take It with You," Common Cause Magazine, p. 9 (May-June 1985); Maxwell Glen, "Finishing a Campaign in the Black Becoming More Prevalent in the House," National Journal, 22 June 1985, pp. 1467-69; Kevin Chaffee, "Money under the Mattress: What Congressmen Don't Spend," Washington Monthly, pp. 32-38 (Sept. 1984). commission threatens to undermine the effectiveness of the prohibitions, restrictions, and limits of the federal election law.

Both external and internal organizational factors act to undermine the effectiveness of the FEC. Congress created the commission with a partisan split and has never clarified the roles of the staff director and general counsel, the two statutory officers of the commission. Consequently, the FEC has failed to have management and policy direction. Congress also consistently underfunds the agency, making it more difficult for the commission to carry out its various responsibilities.

The performance of the FEC is critical to the effective implementation of federal election laws. Congress needs to consider changes in both the structure and the administration of the commission to ensure the proper implementation of federal election laws. ${ }^{48}$

\section{CONCLUSION}

In the spring of 1973, Common Cause chairman John Gardner told the Senate Commerce Committee that "there is nothing in our political system today that creates more mischief, more corruption, and more alienation and distrust on the part of the public than does our system of financing elections. ${ }^{, 49}$ Despite major progress in improving the presidential campaign-financing system,

48. See generally Common Cause, Stalled from the Start (Washington, DC: Common Cause, 1981); see also William C. Oldaker, "Of Philosophers, Foxes, and Finances: Can the Federal Election Commission Ever Do an Adequate Job?" this issue of The Annals of the American Academy of Political and Social Science.

49. Statement of John Gardner, in U.S., Congress, Senate, Commerce Committee, Hearings on $S .372,93 \mathrm{rd}$ Cong., 1st sess. 1973, p. 1. 
that observation remains true today with regard to the congressional campaign-financing system. As former Watergate special prosecutor and current Common Cause chairman Archibald Cox has observed, inaction has resulted in "a Congress still more deeply trapped in the stranglehold of special interests which threatens to paralyze the process of democratic government." Congress needs to complete the reforms begun in the wake of Watergate by fundamentally transforming its own campaign-financing system and by making other adjustments needed to preserve the integrity of presidential public financing, campaign reporting requirements, and limitations on contributions by individuals and PACs.

A consensus has been reached in this country that PACs are inimical to our

50. Archibald Cox, Address before the Commonwealth Club of California, San Francisco, CA, 7 Jan. 1981. system of representative government. ${ }^{51}$ The question now remaining is whether that public consensus can be translated into congressional action.

No solution that may be adopted will be final and perfect. We will always need to reevaluate and adjust any campaign finance system. The presidential public financing system demonstrates the need for periodic adjustments. But more important, the experience of presidential public financing shows us that fundamental improvement in our campaign finance laws is indeed attainable.

We can and must have a better system for financing congressional campaigns. Representative government is at stake.

51. A May 1984 Harris survey, for example, found that "a 70-20 percent majority of all likely voters across the country feels that candidates for federal office should refuse to accept PAC funds." Louis Harris, "PACs: Good or Bad Influence," Harris Survey, 31 May 1984. 